\title{
DEKOLORISASI LIMBAH BATIK MENGGUNAKAN LIMBAH MEDIUM TANAM Pleurotus ostreatus PADA WAKTU INKUBASI YANG BERBEDA
}

\author{
Fitriya Yuni Wulandari, Nuniek Ina Ratnaningtyas, Ratna Stia DEWI
}

Fakultas Biologi, Universitas Jenderal Soedirman, Jalan dr. Suparno 63 Purwokerto 53122

\section{A B S T R A C T}

The batik waste industry is one source of water pollution. It must undergo treatment before discharge into the environment. Batik waste treatment technologies can be done biologically, chemically, physically, or combination of three processes. This research applied a combination of biology and physic technologies, namely used spent mushroom of Pleurotus ostreatus as the decolorization agent. Mycelium of $P$. ostreatus was used as biological agent, and cellulose from spent mushroom was used as physical agent. The aims of this research were to determine the effect of spent mushroom with variation incubation time on batik waste decolorization, and to know the optimum incubation time with highest decolorization batik waste percentage using spent mushroom of $P$. ostreatus. This research used experimental method with completely randomized design (CRD). The data obtained were statistically analyzed using Varian Test (ANOVA) on confidence level of $95 \%$ and $99 \%$ and continued with Honest Significant Difference Test (BNJ) with 95\% confidence level. The result showed that variation incubation time treatment of batik waste decolorization used spent mushroom of $P$. ostreatus provide a highly signification effect on batik waste decolorization. The optimum incubation time was 60 hour $\left(\mathrm{LW}_{5}\right)$, with decolorization percentage was $85,64 \%$.

KEY WORDS: microbes decolorization, batik waste, spent mushroom, Pleurotus ostreatus, incubation time

Penulis korespondensi: FITRIYA YUNI WULANDARI | email: cepritz@yahoo.co.id

\section{PENDAHULUAN}

Semakin pesatnya perkembangan industri saat ini, menghasilkan banyak limbah yang semakin kompleks, termasuk limbah zat warna. Limbah zat warna ditimbulkan akibat penggunaan zat warna sintetik dalam proses produksi. Salah satu industri yang banyak menggunakan zat warna dan menghasilkan limbah zat warna adalah industri kerajinan batik.

Beberapa penelitian penghilangan warna dan senyawa organik yang ada dalam limbah zat warna industri batik telah banyak dilakukan, misalnya dengan cara kimia antara lain degradasi warna dengan reaksi oksidasi, reaksi anaerob dan reaksi fotokatalisis (Rashed dan El-Amin, 2007). Secara fisika dengan koagulasi, sedimentasi, adsorbsi menggunakan karbon aktif, silika dan biomaterial (Mondal, 2008). Beberapa metode fisik dan kimia efektif digunakan untuk mengurangi cemaran limbah warna, namun metode ini memerlukan katalis dan reagen yang lebih mahal (Robinson et al., 2001).

Seiring dengan perkembangan bioteknologi ditemukan suatu cara yang lebih efektif dalam mengurangi pencemaran air akibat limbah zat warna, yaitu dengan menggunakan White rot fungi (Willmott et al., 1998). White rot fungi atau jamur pelapuk putih merupakan organisme yang mempunyai kemampuan untuk mendekolorisasi zat warna sintetik (Barr dan Aust 1994), salah satunya adalah Pleurotus ostreatus (jamur tiram putih).

Mekanisme dekolorisasi oleh jamur terjadi melalui proses adsorbsi zat warna oleh dinding sel jamur (Wikolazka et al., 2002). Menurut Wiloso (1999), perubahan warna miselium jamur dari warna awal menunjukkan proses dekolorisasi yang disebabkan oleh mekanisme adsorbsi zat warna oleh jamur. Selain berperan dalam dekolorisasi, menurut Fadilah et al. (2008) jamur pelapuk putih juga mempunyai kemampuan dalam merombak lignin menjadi selulosa (biodelignifikasi). Menurut Mulyatna et al., (2003) bahan yang mengandung selulosa dapat menyisihkan zat warna melalui proses penyerapan.

Penelitian yang dilakukan menerapkan teknologi pengolahan kombinasi antara cara biologi dan fisika. Salah satu bahan yang sesuai dengan kedua teknologi tersebut adalah limbah medium tanam $P$. ostreatus. Secara biologi yaitu memanfaatkan miselium $P$. ostreatus, cara fisika yaitu memanfaatkan kandungan selulosa dalam limbah medium tanam P. ostreatus sebagai agen dekolorisasi.

Waktu inkubasi berpengaruh terhadap berat zat warna yang terserap pada sorben. Semakin lama waktu inkubasi, maka zat warna yang terserap juga akan semakin besar. Hal ini disebabkan karena semakin lama waktu inkubasi, kontak antara sorben dengan zat warna akan berlangsung lama pula sehingga peluang sorben untuk menyerap zat warna lebih besar (Purnama dan Setiati, 2004). Berdasarkan uraian tersebut, dapat dirumuskan permasalahan berikut; apakah penggunaan limbah medium tanam P.ostreatus dengan lama waktu inkubasi berbeda menghasilkan persentase dekolorisasi yang berbeda pada limbah batik, dan pada waktu inkubasi berapa lamakah penggunaan limbah medium tanam $P$. ostreatus yang memiliki persentase dekolorisasi limbah batik terbaik.

Tujuan dari penelitian ini adalah mengetahui:

1. Pengaruh penggunaan limbah medium tanam $P$. ostreatus dengan lama waktu inkubasi berbeda terhadap dekolorisasi limbah batik. 
2. Waktu inkubasi paling baik pada penggunaan limbah medium tanam $P$. ostreatus yang menghasilkan persentase dekolorisasi tertinggi pada limbah batik.

Berdasarkan penelitian Faraco et al. (2009) $P$. ostreatus mampu mendekolorisasi zat warna asam dengan persentase dekolorisasi sebesar $40 \%$. Menurut penelitian Rani et al., persentase dekolorisasi oleh Daedalea flavida dalam mendekolorisasi metanil yellow adalah sebesar 82 \%. Setiawan et al., (2004) menyatakan bahwa serbuk kayu albasia mampu menyerap zat warna kationik seperti methyen blue dan basic red-18. Berdasarkan penelitian Purnama dan Setiati (2004) waktu optimum adsorbsi limbah tekstil sintetik menggunakan serbuk jerami padi dengan berat $1 \mathrm{~g}$ dalam $100 \mathrm{ml}$ limbah zat warna adalah 48 jam. Penggunaan limbah medium tanam $P$. ostreatus dapat diasumsikan bahwa kandungan miselium dan selulosa di dalamnya masih tinggi, dengan adanya perlakuan lama waktu inkubasi berbeda maka dapat diketahui berapa lama waktu inkubasi yang menghasilkan persentase dekolorisasi tertinggi. Hipotesis yang diajukan dalam penelitian ini adalah:

1. Penggunaan limbah medium tanam jamur $P$. ostreatus dengan lama waktu inkubasi berbeda menghasilkan persentase dekolorisasi yang berbeda pada limbah batik.

2. Penggunaan limbah medium tanam jamur $P$. ostreatus dengan waktu inkubasi 48 jam akan menghasilkan persentase dekolorisasi tertinggi pada limbah batik.

\section{MET O D E}

Metode yang digunakan dalam penelitian ini adalah metode eksperimental dengan menggunakan Rancangan Acak Lengkap (RAL). Penelitian ini terdiri atas satu uji, yaitu uji dekolorisasi menggunakan limbah medium tanam $P$. ostreatus. Volume limbah batik yang digunakan adalah 50 ml, sedangkan limbah medium tanam $P$. ostreatus yang digunakan adalah $25 \mathrm{~g}$. Berikut adalah rancangan perlakuan dekolorisasi limbah batik menggunakan limbah medium tanam P. ostreatus dengan lama waktu inkubasi berbeda:

$\mathrm{LW}_{0}=$ lama waktu inkubasi 0 jam.

$\mathrm{LW}_{1}=$ lama waktu inkubasi 12 jam.

$\mathrm{LW}_{2}=$ lama waktu inkubasi 24 jam.

$\mathrm{LW}_{3}=$ lama waktu inkubasi 36 jam.

$\mathrm{LW}_{4}=$ lama waktu inkubasi 48 jam.

$\mathrm{LW}_{5}=$ lama waktu inkubasi 60 jam.

$\mathrm{LW}_{6}=$ lama waktu inkubasi 72 jam.

$\mathrm{LW}_{7}=$ lama waktu inkubasi 84 jam.

$\mathrm{LW}_{8}=$ lama waktu inkubasi 96 jam.

$\mathrm{LW}_{9}=$ lama waktu inkubasi 108 jam.

$\mathrm{LW}_{10}=$ lama waktu inkubasi 120 jam.
Setiap perlakuan diulang sebanyak 3 kali, sehingga terdapat 33 unit percobaan. Penentuan persentase dekolorisasi adalah sebanyak $5 \mathrm{ml}$ sampel limbah batik yang telah mengalami dekolorisasi dan telah dipisahkan dari padatannya diambil dan diukur absorbansinya menggunakan UV-VIS spektrofotometer dengan panjang gelombang $645 \mathrm{~nm}$. Persentase dekolorisasi diukur menurut rumus dari Rani et al., (2011) yaitu :

$$
\frac{\text { Absorbansi awal - Absorbansi akhir }}{\text { Absorbansi awal }} \times 100 \%
$$

Variabel yang digunakan dalam penelitian ini adalah variabel bebas dan variabel tergantung. Variabel bebasnya adalah lama waktu inkubasi. Variabel tergantungnya adalah kemampuan dekolorisasi limbah medium tanam jamur terhadap limbah batik. Parameter utama adalah persentase dekolorisasi warna limbah batik, dengan parameter pendukungnya adalah pengukuran $\mathrm{pH}$ limbah batik sebelum dan setelah dekolorisasi.

Data persentase dekolorisasi yang diperoleh dianalisis menggunakan uji varian (ANOVA) pada tingkat kepercayaan 95\% dan 99\%. Uji dilanjutkan dengan uji Beda Nyata Jujur (BNJ) dengan tingkat kepercayaan 95\% untuk mengetahui perbedaan pengaruh antar perlakuan.

\section{HASIL DAN PEMBAHASAN}

Hasil perlakuan variasi waktu inkubasi dekolorisasi limbah batik yang mengandung zat warna indigosol yellow oleh limbah medium tanam $P$. ostreatus menunjukkan nilai persentase dekolorisasi antara $33,05 \%$ sampai $85,64 \%$. Nilai persentase dekolorisasi terendah diperoleh pada perlakuan lama waktu inkubasi 12 jam (LW1) yaitu 33,05\%. Persentase dekolorisasi tertinggi diperoleh pada perlakuan lama waktu inkubasi 60 jam (LW5) yaitu sebesar 85,64\%. Besar nilai persentase dekolorisasi berbeda pada setiap variasi lama waktu inkubasi.

Data rata-rata persentase dekolorisasi limbah batik oleh limbah medium tanam $P$. ostreatus selanjutnya dianalisis dengan analisis varian. Hasil analisis varian pada Tabel 1. menunjukkan bahwa lama waktu inkubasi limbah medium tanam jamur $P$. ostreatus berbeda sangat nyata terhadap dekolorisasi limbah batik. Hal ini menunjukkan bahwa dekolorisasi limbah batik sangat dipengaruhi oleh lama waktu inkubasi.

Berdasarkan hasil analisis varian maka hipotesis 1 diterima, yang menyatakan bahwa penggunaan limbah medium tanam jamur P. ostreatus dengan lama waktu inkubasi berbeda menghasilkan persentase dekolorisasi yang berbeda pada limbah batik. Analisis kemudian dilanjutkan dengan uji BNJ, tujuannya yaitu untuk mengetahui perbedaan pengaruh antar perlakuan. Hasilnya dapat dilihat pada Tabel 2.

Tabel 1. Analisis varian persentase dekolorisasi limbah batik oleh limbah medium tanam P. ostreatus (Data hasil tansformasi $\arcsin \sqrt{\mathrm{x}+0,5}$ ).

\begin{tabular}{lcrrrrr}
\hline \multirow{2}{*}{ Sumber Variasi } & $\begin{array}{c}\text { Derajat } \\
\text { Bebas }\end{array}$ & Jumlah Kuadrat & Kuadrat Tengah & \multirow{2}{*}{ F Hitung } & \multicolumn{2}{c}{ F tabel } \\
\cline { 5 - 7 } & 10 & 9482,9359 & 948,2936 & $9,4816^{* *}$ & 2,30 & 3,01 \\
Perlakuan & 22 & 2200,3138 & 100,0143 & & SD $=10,001$ \\
Error & 32 & 11683,2496 & & & KK $=19,866 \%$ \\
Total & & & &
\end{tabular}

Keterangan : ${ }^{* *}=$ berbeda sangat nyata 


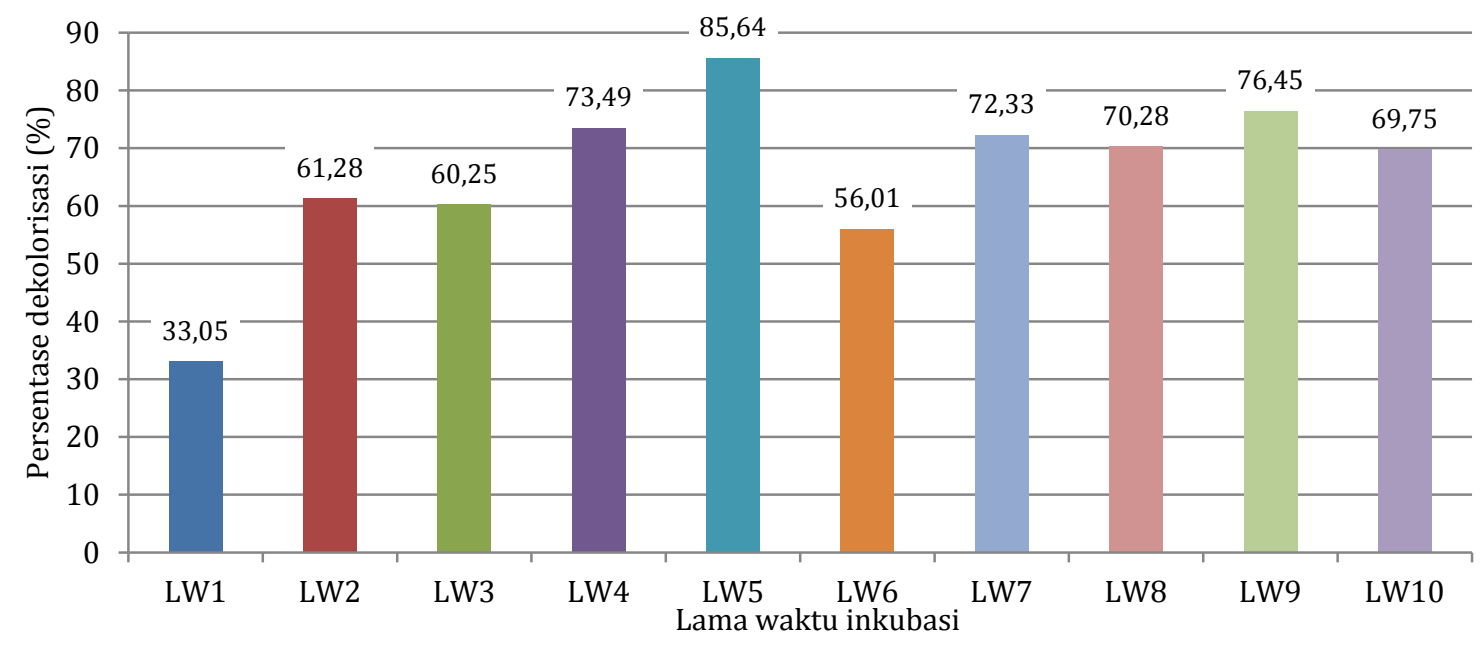

Gambar 1. Histogram aktivitas dekolorisasi limbah batik oleh limbah medium tanam P. ostreatus.

Berdasarkan hasil uji BNJ (Tabel 2), perlakuan antar lama lama waktu inkubasi berbeda nyata. Hal ini menunjukkan bahwa perlakuan lama waktu inkubasi berbeda dalam dekolorisasi limbah batik oleh limbah medium tanam $P$. ostreatus mempunyai pengaruh berbeda dalam mendekolorisasi limbah batik.

Tabel 2. Uji BNJ antar perlakuan waktu inkubasi terhadap persentase dekolorisasi limbah batik oleh limbah medium tanam P. ostreatus (Data hasil tansformasi $\arcsin \sqrt{\mathrm{x}+0,5}$ ).

\begin{tabular}{cc}
\hline Data & Rata-Rata persentase dekolorisasi (\%) \\
\hline LW $_{0}$ & $4.0550 \mathrm{c}$ \\
LW $_{1}$ & $33.5917 \mathrm{~b}$ \\
LW $_{2}$ & $51.9867 \mathrm{ab}$ \\
LW $_{3}$ & $51.2523 \mathrm{ab}$ \\
LW $_{4}$ & $59.4860 \mathrm{ab}$ \\
LW $_{5}$ & $68.9243 \mathrm{a}^{\mathrm{a}}$ \\
LW $_{7}$ & $48.9210 \mathrm{ab}$ \\
LW $_{8}$ & $59.3110 \mathrm{ab}$ \\
LW $_{9}$ & $57.2917 \mathrm{ab}$ \\
LW $_{10}$ & $61.4773 \mathrm{ab}$ \\
\hline
\end{tabular}

Keterangan: angka yang diikuti huruf yang sama berbeda tidak nyata pada BNJ $5 \%$

Variasi waktu inkubasi sangat mempengaruhi proses dekolorisasi limbah batik oleh limbah medium tanam jamur, semakin lama limbah medium tanam jamur diinkubasi dalam limbah batik maka zat warna yang terserap akan semakin banyak. Hal ini terlihat pada Gambar 1. yang menunjukkan bahwa persentase dekolorisasi akan semakin meningkat seiring dengan bertambahnya lama waktu inkubasi, peningkatan persentase dekolorisasi akan menurun jika kemampuan adsorbsi limbah medium jamur telah mencapai pada titik jenuh penyerapan.

Lama waktu inkubasi yang menghasilkan persentase dekolorisasi tertinggi adalah waktu inkubasi 60 jam (LW5) dengan persentase dekolorisasi sebesar $85,64 \%$. Nilai persentase dekolorisasi setelah perlakuan LW5 menunjukkan penurunan, ini membuktikan bahwa perlakuan lama waktu inkubasi 60 jam (LW5) adalah waktu paling baik atau waktu optimum limbah medium tanam jamur dalam mendekolorisasi limbah batik. Lama waktu inkubasi 60 jam juga diasumsikan sebagai titik jenuh penyerapan.

Pernyataan di atas sesuai dengan pernyataan Purnama dan Setiati (2004) bahwa waktu inkubasi berpengaruh terhadap daya adsorbsi dalam proses dekolorisasi terhadap limbah cair. Semakin lama waktu inkubasi, maka zat warna terserap yang dihasilkan juga akan semakin besar. Hal ini disebabkan karena semakin lama waktu inkubasi, kontak antara sorben dengan zat warna akan berlangsung lama pula sehingga peluang sorben untuk menyerap zat warna lebih besar, dengan kata lain zat warna yang terserap pun akan semakin banyak, tetapi pada suatu waktu tertentu proses adsorbsi akan berhenti atau tingkat daya serapnya berkurang jika sorben sudah pada titik kritis daya serapnya.

Mekanisme dekolorisasi oleh jamur dapat terjadi melalui dua cara yaitu secara nonenzimatik dan enzimatik (Wikolazka et al., 2002). Mekanisme dekolorisasi secara nonenzimatik oleh jamur terjadi melalui proses adsorbsi pewarna oleh dinding sel jamur. Hal ini dibuktikan dengan perubahan warna miselium $P$. ostreatus dari semula berwarna putih menjadi kuning kehijauan. Menurut Wiloso (1999), perubahan warna miselium jamur dari warna awal menunjukkan proses dekolorisasi yang disebabkan oleh mekanisme adsorbsi zat warna oleh jamur. Demikian pula pernyataan Yulisna (2000), yang menyatakan bahwa perubahan warna pellet jamur dari warna pellet awal menunjukkan proses dekolorisasi yang disebabkan oleh mekanisme adsorbsi pewarna oleh jamur.

Menurut Awaludin et al., (2001) dinding sel jamur mengandung matriks ekstraseluler yang tersusun dari berbagai macam senyawa organik yaitu enzim, protein, dan polisakarida. Selain itu dinding sel juga mengeluarkan gel yang berfungsi sebagai zat perekat. Gel ini mampu menyerap pewarna yang ditambahkan ke dalam medium. Miselium jamur bersifat hidrofobik 
dan zat warna bersifat hidrofilik, sehingga dengan adanya gel yang dikeluarkan menyebabkan terjadinya interaksi antara miselium dengan zat pewarna. Interaksi hidrofobik-hidrofilik miselium jamur dan pewarna menyebabkan mekanisme adsorbsi.

Adsorbsi atau penyerapan adalah proses pemisahan komponen tertentu dari suatu fluida berpindah ke suatu permukaan zat padat penyerap (adsorben) Daya adsorbsi dipengaruhi oleh sifat fisika dan kimia dari bahan yang digunakan sebagai adsorben, pelarut, jenis zat yang dilarutkan, serta banyaknya bahan padat yang dipergunakan sebagai bahan penyerap. Selain itu $\mathrm{pH}$, waktu inkubasi, tekanan, suhu juga merupakan faktor yang mempengaruhi daya adsorbsi (Purnama dan Setiati, 2004).

Mekanisme dekolorisasi secara enzimatik oleh jamur menurut Wikolazka et al., (2002) dan Sclegel dan Scmith (1994) melibatkan enzim ekstraseluler kompleks yang disekresikan oleh jamur ke dalam medium kultivasi. Enzim tersebut yaitu lignin peroksidase (LiP), mangan dependent peroksidase (MnP), oksidase 1 glukosa, oksidase 2 glukosa, fenol oksidase, dan laccase. Adanya enzim-enzim tersebut yang sifatnya nonspesifik terhadap substrat memungkinkan jamur mendekolorisasi limbah batik. Enzim inilah yang bertanggung jawab terhadap pemecahan ikatan aromatik pada senyawa warna kompleks.

Aktifitas $P$. ostreatus dalam proses dekolorisasi menyebabkan terjadinya perubahan derajat keasaman $(\mathrm{pH})$ limbah batik. Hasil penelitian menunjukkan bahwa terjadi penurunan $\mathrm{pH}$ limbah batik setelah dekolorisasi berlangsung, nilai $\mathrm{pH}$ awal limbah batik adalah 7,74 sedangkan nilai $\mathrm{pH}$ akhir penelitian berkisar antara 6.53 sampai 7.48. Berdasarkan hasil penelitian menunjukkan bahwa semakin asam nilai pH maka semakin besar persentase dekolorisasi yang dihasilkan. Hal ini sesuai dengan pernyataan Hadianto (2004), bahwa pada kondisi pH yang semakin kuat atau asam maka nilai absorbansi semakin menurun sehingga persentase dekolorisasi semakin besar.

Selain karena kemampuan dekolorisasi zat warna indigosol yellow secara nonenzimatik dan enzimatik oleh miselium $P$. ostreatus, proses dekolorisasi juga dikarenakan oleh kemampuan komponen selulosa yang terkandung dalam limbah medium tanam yang mampu menyerap zat warna. Selulosa mampu menyerap zat warna yang terkandung dalam limbah batik secara adsorbsi. Mulyatna et al., (2003) melaporkan bahwa setiap bahan yang mengandung selulosa dapat menyisihkan zat warna melalui proses penyerapan.

Penyerapan zat warna oleh sorben merupakan proses adsorbsi secara fisik melalui pori sorben. Komponen limbah medium tanam jamur tersebut adalah serbuk kayu. Soedrajat (1979) menyatakan bahwa serbuk kayu diasumsikan mempunyai susunan inti kayu secara umum yaitu selulosa, hemiselulosa, dan lignin. Selulosa dan hemiselulosa merupakan polisakarida sedangkan lignin adalah suatu polimer yang komplek dengan berat molekul yang tinggi. Menurut Eligwe et al., (1999) hemiselulosa dan selulosa memiliki kemampuan penyerapan lebih baik dibandingkan dengan lignin.

Mekanisme penyerapan zat warna oleh selulosa dalam limbah medium tanam jamur adalah sebagai berikut. Struktur molekul selulosa serbuk kayu dalam limbah medium tanam jamur mengandung gugus hidroksil atau gugus $\mathrm{OH}$. Zat warna tekstil mengandung gugus klorida yang dapat bereaksi dengan gugus $\mathrm{OH}$ dari selulosa, selain itu terjadi pula ikatan hidrogen antara atom nitrogen didalam zat warna tekstil dengan atom hidrogen dari gugus $\mathrm{OH}$ dalam selulosa, dengan terdapatnya ikatan-ikatan tersebut maka zat warna dapat terikat pada serat selulosa serbuk kayu, sehingga zat warna dapat mewarnai serat selulosa (Peters, 1975).

Komponen utama limbah medium tanam jamur yang digunakan dalam penelitian ini berasal dari serbuk kayu albasia (Paraserianthes falcataria). Hasil penelitian menunjukkan bahwa kandungan selulosa awal medium tanam jamur sebelum digunakan sebagai medium penanaman jamur adalah 41,60\%, sedangkan kandungan lignin awal adalah 16,88\%. Hal ini sesuai dengan pernyataan Martina et al. (2002) bahwa kandungan selulosa kayu albasia adalah adalah 40,99\%, Pari (1996) menyatakan bahwa kandungan lignin serbuk gergaji kayu albasia termasuk sedang yaitu berada diantara $18-33 \%$.

Kandungan selulosa medium tanam P. ostreatus yang telah digunakan sebagai medium penanaman jamur sampai enam kali masa panen adalah 34,16\%, sedangkan kandungan ligninnya sebesar 6,28\%. Belewu (2006) mempelajari inkubasi P. sajor caju dalam media serbuk kayu menemukan bahwa untuk 60 hari inkubasi kandungan lignin dalam serbuk gergaji berkurang dari 44,36\% menjadi 25,53\%. Pengurangan kandungan selulosa juga terjadi namun jumlah pengurangannya lebih kecil, yaitu dari kandungan 31,99\% menjadi 30,89\%. Hal ini menunjukkan bahwa jamur lebih cenderung untuk menguraikan lignin dibandingkan dengan selulosa.

Kandungan dalam limbah medium tanam $P$. ostreatus selain mengandung miselium $P$. ostreatus diduga juga mengandung miselium jamur lain. Jamurjamur tersebut diasumsikan juga mempunyai peran dalam proses dekolorisasi. Identifikasi dilakukan dengan cara mengamati ciri morfologi jamur baik secara makroskopis maupun mikroskopis. Berdasarkan hasil penelitian ditemukan ada tiga macam jamur yang terdapat dalam limbah medium tanam jamur yaitu Penicillium sp., Trichoderma sp., dan Aspergillus sp. Berdasarkan penelitian Handayani (2005) menunjukkan bahwa jamur kontaminan yang terdapat pada medium tanam jamur ada 7 genus, yaitu Aspergillus, Penicillium, Paecillomyces, Trichoderma, Rhizopus, Fusarium dan Syncephalastrum. 


\section{K E S I M P U L A N}

Berdasarkan hasil penelitian yang telah dilakukan maka dapat diambil kesimpulan sebagai berikut:

1. Penggunaan limbah medium tanam P. ostreatus dengan lama waktu yang berbeda menghasilkan persentase dekolorisasi yang berbeda pula.

2. Waktu inkubasi 60 jam merupakan waktu inkubasi terbaik pada penggunaaan limbah medium tanam P.ostreatus sebagai agen dekolorisasi limbah batik dengan persentase dekolorisasi tertinggi yaitu sebesar 85,64\%.

\section{DAFT AR REFERENSI}

Awaludin R, Darah I, Ibrahim CO, Abd MU. 2001. Decolorozation of commercially available synthetic dyes by the white rot fungus Phanerochaete chrysosporium ME446 (ATCC 34541). Proceeding NSF Workshop 2001; Kuala Lumpur.

Barr DP, Aust SD. 1994. Mechanisms white-rot fungi use to degrade pollutants. Environ Sci. Technol. 28: 78-87.

Belewu MA. 2006. Conversion of masonia tree sawdust and cotton plant by product into feed by white rot fungus (Pleurotus sajor caju). African Journal of Biotech. 5: 503 - 504.

Eligwe CA, Okule NB, Nwambu CO, Nwoko CI. 1999. Adsorption thermodynamics abd kinetics of mercury (ii), cadmium (ii) and lead (ii) on lignite. Chem. Eng. Technol. 22: 45-49.

Fadilah, Distantina S, Artati EK, Jumari A. 2008. Biodelignifikasi batang jagung dengan jamur pelapuk putih Phanerochaete chrysosporium. Ekuilibrium. 1(7): 7 - 11.

Faraco V, Pezzella C, Miele A, Giardina P, Sannia G. 2009. Bioremediation of colored industrial wastewaters by the whiterot fungi Phanerochaete chrysosporium and Pleurotus ostreatus and their enzymes. Biodegradation. 20: 209-220.

Hadianto AD. 2000. Pengaruh TA dan Penambahan $\mathrm{H}_{2} \mathrm{O}_{2}$ Terhadap Elektrodekolorisasi Pewarna Indigo [skripsi]. Universitas Diponegoro-Semarang.

Handayani T. 2005. Isolasi Dan Identifikasi Kapang Kontaminasi Pada Media Pertumbuhan (Bag Log) Jamur Budidaya Serta Uji Kemampuan Selulotiknya [tesis]. Universitas DiponegoroSemarang.

Martina A, Yuli N, Sutisna M. 2002. Optimasi beberapa faktor fisik terhadap laju degradasi selulosa kayu albasia (Paraserianthes falcataria (L.) nielsen dan karboksimetilselulosa (cmc) secara enzimatik oleh jamur. Jurnal Natur Indonesia. 4(2): 156-163.
Mondal S. 2008. Methods of dye removal from dye house effluent Environmental Engineering Science. 25(3): 383-396.

Mulyatna L, Pradiko H, Nasution UK. 2003. Pemilihan persamaan adsorbsi isotherm pada penentuan kapasitas adsorbsi kulit kacang tanah terhadap zat warna Remazol Golden Yellow 6. Infomatek. 5(3): 131-143.

Pari G. 1996. Analisis Komponen Kimia dari Kayu Sengon dan Kayu Karet pada Beberapa Macam Umur. Buletin Penelitian Hasil Hutan. 14: 321- 327.

Peters RH. 1975. Textile Chemistry Vol. III, The Physical Chemistry of Dying. New York: Elsevier Scientific Publishing Company.

Purnama H, Setiati. 2004. Adsorbsi limbah tekstil sintesis dengan jerami padi. Jurnal Teknik Gelagar. 15(1): 1-9.

Rani C, Asim K, Jana, Bansal A. 2011. Studies on the Biodegradation of Azo Dyes by White rot Fungi Daedalea Flavida in the Absence of External Carbon Source. 2nd International Conference on Environmental Science and Technology, IPCBEE, (6). Singapore: IACSIT Press.

Rashed MN, El-Amin AA. 2007. Photocatalytic degradation of methyl orange in aqueous $\mathrm{TiO} 2$ under different solar irradiation source. Int.j.Phys.Sci. 2(3) : 73-81.

Robinson T, McMullan G, Marchant R, Nigam P. 2001. Remediation of dyes in textile effluent: a critical review on current treatment technologies with a proposed alternative. Bioresour Technol. 77: 247-255.

Sclegel HG, Smith K. 1994. Mikrobiologi umum [diterjemahkan oleh Baskoro RM,Watimena JR]. Yogyakarta: Gadjah Mada University Press.

Setiawan AH, Wiloso EL, Soleha R, Barliati V, Anggraeni LF. 2004. Peningkatan kemampuan daya serap sorben serbuk gergaji dengan pengsulfonasian dan pengujiannya dengan zat warrna tekstil kationik. Alchemy. 2(3): 10-15.

Soedrajat. 1979. Kimia Kayu. Bogor: Institut Pertanian Bogor.

Wikolazka AJ, Dest JKR, Malarczky E, Wardas W, Leonowicz A. 2002. Fungi and their ability to decolorization azo and antroquinonoc dyes. Enzime and Microbial Technology. 30: 566-572.

Willmott N, Guthrie J, Nelson G. 1998. The biotechnology approach to colour removal from textile effluent. J Soc Dyers Colour. 114: 38-41.

Wiloso EI. 1999. Dekolorisasi limbah cair berwarna yang mengandung orange oleh Penicillium sp. Prosiding Semnas VIII Kimia dalam Industri dan Lingkungan; 2009 nov 16-17.

Yulisna V. 2000. Dekolorisasi Limbah Cair Berwarna Yang Mengandung Orange oleh Penicillium sp. Bogor: Institut Pertanian Bogor. 